\title{
Elevated water temperature impairs gamete production in male narrow-clawed crayfish Pontastacus leptodactylus (Eschscholtz, 1823)
}

\author{
Ardavan Farhadi ${ }^{*}$ and Muzaffer Mustafa Harlıoglu \\ Fisheries Faculty, Firat University, 23119 Elazig, Turkey
}

\begin{abstract}
Water temperature is one of the major environmental factors affecting the reproductive output of freshwater crayfish. The reproduction of freshwater crayfish only occurs in a limited water temperature range and minor changes in water temperature could have negative impacts on this biological process. Therefore, understanding the potential effects of temperature on the reproductive output of crayfish is important from both an ecological and aquaculture point of view. Spermatozoal production, hepatosomatic index (HSI), gonado-somatic index (GSI), testicular index (TI), and vas deferens index (VDI) were measured in Pontastacus leptodactylus maintained at $7.5,11$, and $19^{\circ} \mathrm{C}$ during the reproductive season. It was found that the highest temperature significantly degrades the production of spermatozoa and VDI when compared to the crayfish maintained at lower temperatures $(P<0.05)$. On the other hand, water temperature did not significantly affect the values of HSI, GSI, and TI $(P>0.05)$. Furthermore, the highest temperature caused a negative impact on the vas deferens characterized by a softer and more adhesive texture. In conclusion, this study demonstrated that elevated water temperature has a negative impact on gamete production of male P. leptodactylus, as a cold water crayfish species, and may subsequently affect the whole reproduction process.
\end{abstract}

Keywords: sperm / Decapoda / global warming / Crustacean

Résumé - La température élevée de l'eau nuit à la production de gamètes chez l'écrevisse à pattes grêles mâle Pontastacus leptodactylus (Eschschscholtz, 1823). La température de l'eau est l'un des principaux facteurs environnementaux qui influent sur le rendement reproducteur des écrevisses d'eau douce. La reproduction des écrevisses ne se produit que dans une plage de température de l'eau limitée et des changements mineurs de la température de l'eau pourraient avoir des effets négatifs sur ce processus biologique. Par conséquent, il est important de comprendre les effets potentiels de la température sur le rendement reproducteur des écrevisses, tant du point de vue écologique que du point de vue de l'aquaculture. La production de spermatozoïdes, l'indice hépatosomatique (HSI), l'indice gonado-somatique (GSI), l'indice testiculaire (TI) et l'indice vas deferens (VDI) ont été mesurés chez Pontastacus leptodactylus maintenu à $7.5,11$ et $19^{\circ} \mathrm{C}$ pendant la saison de reproduction. Il a été constaté que la température la plus élevée dégrade significativement la production de spermatozoïdes et le VDI par rapport aux écrevisses maintenues à des températures plus basses $(P<0,05)$. Par contre, la température de l'eau n'a pas eu d'effet significatif sur les valeurs de HSI, GSI et TI $(P>0,05)$. De plus, la température la plus élevée a eu un impact négatif sur le canal déférent caractérisé par une texture plus douce et plus adhésive. En conclusion, cette étude a démontré que la température élevée de l'eau a un impact négatif sur la production de gamètes de $P$. leptodactylus mâle, espèce d'écrevisse d'eau froide, et peut par la suite affecter l'ensemble du processus de reproduction.

Mots-clés : sperme / Décapode / réchauffement global / Crustacé

\footnotetext{
*Corresponding author: Farhadi219@yahoo.com
} 


\section{Introduction}

Pontastacus leptodactylus (Eschscholtz, 1823), also known as the narrow-clawed crayfish, Danube crayfish, Galician crayfish or Turkish crayfish, is widely distributed in Eastern Europe, and the Middle East (Köksal, 1988). This species is native to a vast area which extends from Iran in the east, Austria in the west, Russia in the north, and Greece in the south. In addition, P. leptodactylus has been introduced into many countries in Europe and Asia (Skurdal and Taugbøl, 2002; Harlioglu, 2004; Gherardi and Souty-Grosset, 2017). Pontastacus leptodactylus is also considered as an economic crayfish species that can be used for aquaculture purposes (Wickins and Lee, 2002).

Global warming is characterized by the increase in the surface temperatures in terrestrial and aquatic ecosystems. It alters the main ecological processes and the distribution of aquatic species (Poff et al., 2002). Aquatic species of warm waters are well adapted to high temperatures, while aquatic animals of cold waters are more vulnerable to climate warming (Jeppesen et al., 2010). The body temperature of cold-blooded aquatic animals is adjusted by water temperature. Therefore, the water temperature controls the main biological processes such as growth, behavior (Wittmann and Pörtner, 2013), moulting (Hammond et al., 2006), immune response (Jiravanichpaisal et al., 2004) and reproduction (Tropea et al., 2010; Yazicioglu et al., 2018) in aquatic animals.

The effects of temperature on crayfish reproduction depends on the species thermal tolerance, geographical distribution and response based on physiological and behavioral adaptations (Harloglu and Farhadi, 2017). It has been shown that water temperature affects ovarian development, spawning rate (Yeh and Rouse, 1995; Tropea et al., 2010), mating time (Yazicioglu et al., 2018) and sperm production (Bugnot and López Greco, 2009a, b) of crayfish species.

Reproduction in P. leptodactylus generally occurs in cold water at $7-12{ }^{\circ} \mathrm{C}$ (Skurdal and Taugbøl, 2002) and hence is likely to be affected by the incremental increase in water temperature caused by climate warming. However, the effect of higher water temperatures on the sperm quality of male freshwater crayfish is not known. Motility and fertilization success are two common methods for assessment of sperm quality in animals bearing flagellate spermatozoa (Hatef et al., 2009). However, the spermatozoon in crayfish is aflagellate and immotile (Tudge et al., 2009; Niksirat et al., 2013a, b; Kouba et al., 2015; Yazicioglu et al., 2016) and the spermatozoal mass is covered by a spermatophore protective wall during the stay in the vas deference of the male or postmating storage on the body of the female (Jamieson and Tudge, 2000; Niksirat et al., 2014a; Niksirat and Kouba, 2016) rather than immersion in seminal plasma like other animals such as fish and mammals. Therefore, techniques such as sperm counting have been developed to evaluate gamete quality in the male decapod crustaceans (Farhadi et al., 2018; Harlioglu et al., 2018). This study aims to investigate the effects of water temperature on the spermatozoal production, hepatosomatic index (HSI), gonado-somatic index (GSI), testicular index (TI), and vas deferens index (VDI) of the narrow-clawed crayfish P. leptodactylus.

\section{Materials and methods}

\subsection{Animals and sampling process}

Thirty-six mature males of $P$. leptodactylus (mean weight \pm SE: $63.5 \pm 3.7 \mathrm{~g}$, range: $44-107 \mathrm{~g}$, mean carapace length \pm SE: $63.2 \pm 1.1 \mathrm{~mm}$, range: $55-74 \mathrm{~mm}$ ) were captured from Keban Dam Lake (Elazig, Turkey) in January, in the breeding season, 2018. The carapace length and weight of each crayfish was determined using a digital caliper and a digital balance, respectively.

\subsection{Experimental design}

Crayfish were held in three $1000 \mathrm{~L}$ fiberglass tanks containing artificial shelters constructed from $150 \mathrm{~mm}$ PVC pipes for 2 weeks for acclimation to the lab environment. Twelve crayfish for each treatment were weighted and randomly placed into nine $90 \mathrm{~L}$ aquaria and reared in the experimental conditions for 5 weeks at three different water temperatures $\left(7.5,11\right.$ and $\left.19^{\circ} \mathrm{C}\right)$. The mean weight and length of males was not significantly different between treatments. During the experiment, dissolved oxygen, and $\mathrm{pH}$ were determined daily. Mean dissolved oxygen, and $\mathrm{pH}$ were $7.8 \pm 1 \mathrm{mg} / \mathrm{L}$ and $7.9 \pm 0.2$, respectively. Crayfish were fed a commercial feed containing $40.7 \%$ protein and $16.8 \%$ lipid two times per day and approximately $1 \%$ of body weight (Farhadi and Jensen, 2016). Cold water $\left(7.5^{\circ} \mathrm{C}\right.$ ) was provided from outdoor tanks and aquarium heaters were used to provide the other test temperatures $\left(11\right.$ and $19^{\circ} \mathrm{C}$ ) (Skurdal and Taugbøl, 2002; Bugnot and López Greco, 2009a; Tropea et al., 2010). No mortality was observed during the experiment in any treatments.

\subsection{Reproductive parameters}

At the end of the experiment, eight crayfish were dissected from each treatment to investigate the following reproductive parameters. The whole reproductive system, vas deferens, testes and hepatopancreas were weighted. GSI, VDI, TI, and HSI were calculated (Harloglu et al., 2012, 2013) as follows:

- Gonado-somatic index (\%): (reproductive system wet weight/body wet weight $) \times 100$

- Vas deferens index (\%): (vas deferens wet weight/body wet weight) $\times 100$

- Testicular index (\%): (testes wet weight/body wet weight) $\times 100$

- Hepatosomatic index (\%): (hepatopancreas wet weight/ body wet weight) $\times 100$

\subsection{Spermatozoa extraction and counting}

Equal amounts of the distal part of the vas deferens of each crayfish was cut into small pieces using sterile surgical blades in $1 \mathrm{~mL}$ of physiological solution $(0.9 \% \mathrm{NaCl})$ to prepare the spermatophore solution (Harlioglu et al., 2012). The solution of each sample was subsequently transferred into $2 \mathrm{~mL}$ microtubes. Spermatozoa of crayfish were extracted according to Farhadi et al. (2018). Then, spermatozoal number was 
counted under a light microscope using a hemocytometer (Bugnot and López Greco, 2009a, b; Harlioglu et al., 2012, 2013).

\subsection{Statistical analysis}

The normality and homoscedasticity of the data were confirmed using Kolmogorov-Smirnov and Leven's test, respectively. To compare differences among the treatments a one-way ANOVA was used. Significant differences between groups were determined using Tukey's HSD tests for post hoc comparisons. Data were analyzed using SPSS version 16.0 (2007 SPSS Inc.). The level of significance for all analyses was determined at $P<0.05$.

\section{Results}

The number of crayfish spermatozoa and VDI were significantly affected by the water temperature $(P<0.05)$. Higher numbers of spermatozoa were obtained in the crayfish exposed to $7.5^{\circ} \mathrm{C} \quad\left(2.65 \times 10^{7} \pm 0.35\right)$ and $11^{\circ} \mathrm{C}$ $\left(3.22 \times 10^{7} \pm 0.48\right)$ compared to $19^{\circ} \mathrm{C}\left(1.25 \times 10^{7} \pm 0.17\right)(P$ $<0.05$ ) (Fig. 1). The results revealed that HSI, GSI, and TI were not affected by the different water temperatures $(P>$ $0.05)$. However, a significant $(P<0.05)$ reduction in VDI was observed at higher temperature (Figs. 2A-DA-D). It was found that $19^{\circ} \mathrm{C}$ gave rise to anomalies in the vas deferens of crayfish characterized by a softer and more adhesive texture. The spermatozoa of crayfish exposed to $19^{\circ} \mathrm{C}$ were mostly aggregated and a single separated spermatozoon rarely could be observed.

\section{Discussion}

The present study showed that the elevated water temperature impairs the spermatozoal production and increases abnormality in the vas deferens of crayfish, and subsequently reduces the spermatophores and spermatozoal number in P. leptodactylus. More than 100 proteins including respiratory, transport, cell defense, and cytoskeleton proteins have been identified in the spermatophores of crayfish. They are responsible for numerous vital functions necessary for the process of reproduction in crayfish such as capacitation and fertilization (Niksirat et al., 2014b, 2015, 2016). These proteins need an optimum temperature to maintain their respective structure and activity. Therefore, the occurrence of more adhesive spermatozoa at $19^{\circ} \mathrm{C}$ could be due to the denaturation of spermatozoal and spermatophore proteins and subsequent impairment of the whole gamete in crayfish; as observed in other animals (Thijssen et al., 2014).

It has been shown that a short term in vitro incubation of male gametes at high temperatures $\left(40\right.$ and $\left.75^{\circ} \mathrm{C}\right)$ could seriously damage spermatozoa in $P$. leptodactylus. Also, higher temperatures probably alter the biomechanical properties of the spermatophore layers and cause their subsequent adhesion to spermatozoa, which may reduce extraction of intact spermatozoa (Farhadi et al., 2018). In crayfish, the highest gamete production and vasa deferentia weight occur during the peak of their reproductive season. Bugnot and

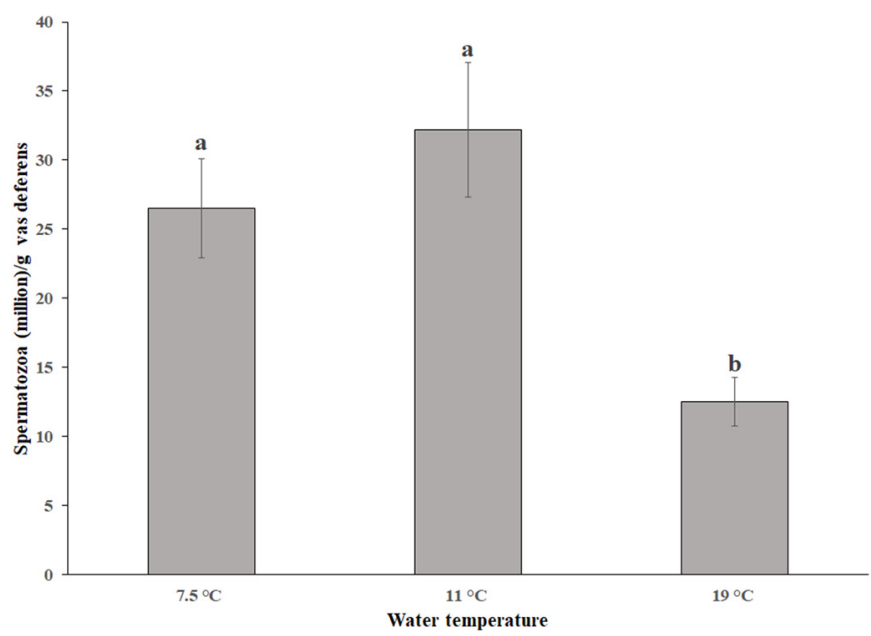

Fig. 1. Effect of water temperature on the number of spermatozoa in male narrow-clawed crayfish. Different letters on bars show significant difference at $P<0.05$. Data are presented as mean \pm SE.

López Greco (2009a) showed that spermatozoal production and weight of the vasa deferentia increased in Cherax quadricarinatus (von Martens, 1868) during the breeding season in summer, while the weight of the testes rose during the non-breeding season in winter. The narrow-clawed crayfish is a cold water freshwater species and the mating of this species takes place during the autumn when the water temperature is about $7-12{ }^{\circ} \mathrm{C}$ (Skurdal and Taugbøl, 2002). The observation of the highest spermatozoal production and VDI at lower temperatures $\left(7.5\right.$ and $\left.11^{\circ} \mathrm{C}\right)$ compared to $19^{\circ} \mathrm{C}$ indicates that water temperature is a critical factor for successful reproduction in P. leptodactylus.

Similarly, high temperatures $\left(29-30^{\circ} \mathrm{C}\right)$ showed a negative impact on the spermatozoal quality of the shrimp Penaeus setiferus (Linnaeus, 1767). On the other hand, lower temperature $\left(25-27^{\circ} \mathrm{C}\right)$ postponed spermatophore degradation and melanization in this species (Bray et al., 1985; Pascual et al., 1998). Perez-Velazquez et al. (2001) reported that high water temperature $\left(29^{\circ} \mathrm{C}\right)$ reduced spermatozoal number and increased abnormal spermatozoa compared to a lower water temperature $\left(26^{\circ} \mathrm{C}\right)$ in Penaeus vannamei (Boone, 1931). In addition, it has been reported that elevated water temperatures $\left(30-33^{\circ} \mathrm{C}\right)$ caused stressful situations in male penaeid shrimps (Pascual et al., 1998; Sánchez et al., 2001; Pascual et al., 2003).

According to King et al. (2003) high water temperatures alter the concentration of reproductive hormones by inducing stress responses. Burt et al. (2011) stated that this situation probably affects offspring outcomes. On the other hand, there is not any information regarding the impact of high temperatures on the morphological and molecular characteristics of gametes in decapods. However, studies show that mammalian and fish spermatozoa are extremely sensitive to high temperature (Dadras et al., 2017). For example, high temperatures increase the mortality and percentage of abnormal spermatozoa (Borg et al., 1993), change acrosome and plasma membrane integrity (Borg et al., 1993; Safaa et al., 2008), and affect spermatozoon chromatin stability (Paul et al., 2008; Pérez-Crespo et al., 2008) in mammals. 

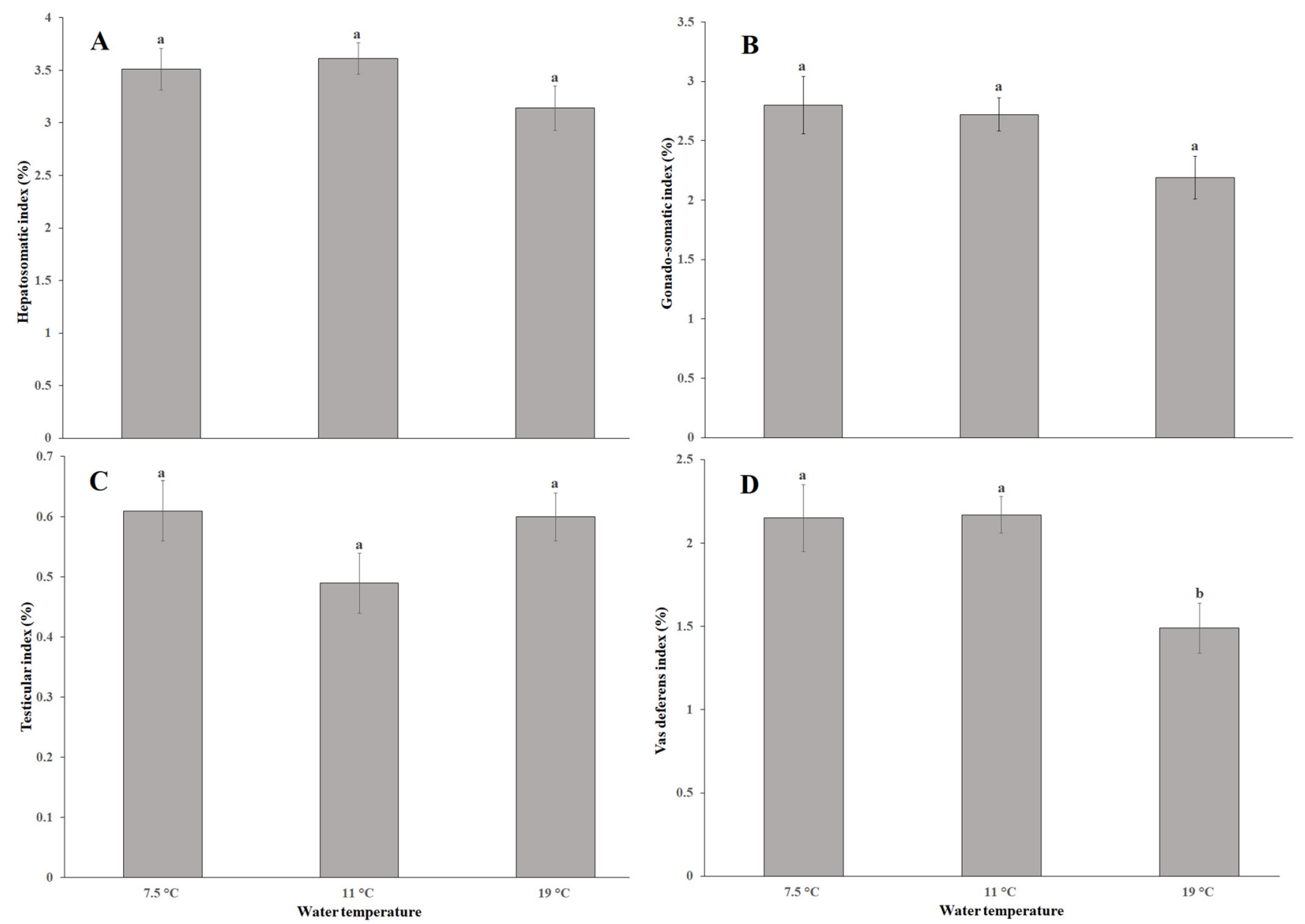

Fig. 2. Effect of water temperature on A: HSI, B: GSI, C: TI, and D: VDI of male narrow-clawed crayfish. Different letters on bars show significant difference at $P<0.05$. Data are presented as mean $\pm \mathrm{SE}$.

The reproduction of crayfish could be affected by enhanced water temperatures arising from global warming. Seasonal changes in water temperature affect hormonal function and either induce or suppress gametogenesis. However, higher than normal temperatures have deleterious effects on gametogenesis (Pankhurst and King, 2010). King et al. (2003) found that exposure to high water temperature had deleterious impacts on the secretion of steroid hormones and hepatic vitellogenin synthesis and caused reduction in maternal investment and gamete viability in Atlantic salmon Salmo salar (Linnaeus, 1758). Similarly, high water temperature had an inhibitory effect on spermiogenesis in S. salar and rainbow trout Oncorhynchus mykiss (Walbaum, 1792). Water temperature had significant effects on the blood concentration of gonadal steroids testosterone and 11-ketostestosterone in O. mykiss (Manning and Kime, 1985), showing that water temperature has a permissive role in male gametogenesis (Pankhurst and King, 2010).

\section{Conclusion}

Our results show that elevated water temperature negatively affects the reproductive output of the $P$. leptodactylus. Further studies are required to investigate the potential effects of elevated water temperatures on the reproductive output of native crayfish species. Also, future studies are needed to consider the effect of high temperatures on the morphological and molecular (i.e., proteome and lipid profiles) characteristics of crayfish spermatozoa.

Acknowledgements. This study was conducted as a part of Ardavan FARHADI's doctoral research, "An investigation on the effects of serotonin and photoperiod on the reproduction efficiency of freshwater crayfish Pontastacus leptodactylus (Eschscholtz, 1823)," supported by Firat University (Project No: SÜF.18.07). We gratefully thank Dr. Christopher Tudge for English correction of the manuscript.

\section{References}

Borg KE, Lunstra DD, Christenson RK. 1993. Semen characteristics, testicular size, and reproductive hormone concentrations in mature Duroc, Meishan, Fengjing, and Minzhu boars. Biol Reprod 49: 515-521.

Bray WA, Leung-Trujillo JR, Lawrence AL, Robertson SM. 1985. Preliminary investigation of the effects of temperature, bacterial inoculation, and EDTA on sperm quality in captive Penaeus setiferus. $J$ World Aquacult 16: 250-257. 
Bugnot AB, López Greco LS. 2009a. Sperm production in the red claw crayfish Cherax quadricarinatus (Decapoda, Parastacidae). Aquaculture 295: 292-299.

Bugnot AB, López Greco LS. 2009b. Structural alterations in the male reproductive system of the freshwater crayfish, Cherax quadricarinatus (Decapoda, Parastacidae). J Invertebr Pathol 102: 160-166.

Burt JM, Hinch SG, Patterson DA. 2011. The importance of parentage in assessing temperature effects on fish early life history: a review of the experimental literature. Rev Fish Biol Fisher 21: 377-406.

Dadras H, Dzyuba B, Cosson J, Golpour A, Siddique MAM, Linhart O. 2017. Effect of water temperature on the physiology of fish spermatozoon function: a brief review. Aquac Res 48: 729-740.

Farhadi A, Jensen MA. 2016. Effects of photoperiod and stocking density on survival, growth and physiological responses of narrow clawed crayfish (Astacus leptodactylus). Aquac Res 47: 2518-2527.

Farhadi A, Harlıoglu MM, Gür S, Can Acısu T. 2018. Optimization of the incubation time and temperature for spermatozoa extraction in freshwater crayfish Pontastacus leptodactylus (Eschscholtz, 1823). Anim Reprod Sci 193: 153-157.

Gherardi F, Souty-Grosset C. 2017. Pontastacus leptodactylus (amended version of 2016 assessment). The IUCN Red List of Threatened Species 2017: e.T153745 A120103207. http://dx.doi. org/10.2305/IUCN.UK 2017-3. RLTS.T153745 A120103207. en. (Accessed: 30 May, 2018).

Hammond KS, Hollows JW, Townsend CR, Lokman PM. 2006. Effects of temperature and water calcium concentration on growth, survival and moulting of freshwater crayfish, Paranephrops zealandicus. Aquaculture 251: 271-279.

Harloglu MM. 2004. The present situation of freshwater crayfish, Astacus leptodactylus (Eschscholtz, 1823) in Turkey. Aquaculture 230: 181-187.

Harloglu MM, Farhadi A. 2017. Factors affecting the reproductive efficiency in crayfish: implications for aquaculture. Aquac Res 48: 1983-1997.

Harloglu MM, Kutluyer F, Gür S. 2012. An investigation on the sperm number and reproductive parameters of males in wild caught freshwater crayfish (Astacus leptodactylus, Eschscholtz). Anim Biol 62: 409-418.

Harlıoglu MM, Köprücü K, Harlıglu AG, et al. 2013. Effect of dietary n-3 series fatty acids on sperm production in the freshwater crayfish, Astacus leptodactylus (Eschscholtz)(Astacidae). Aquac Int 21: 273-282.

Harloglu MM, Farhadi A, Gür S. 2018. Determination of sperm quality in decapod crustaceans. Aquaculture 490: 185-193.

Hatef A, Niksirat H, Alavi SMH. 2009. Composition of ovarian fluid in endangered Caspian brown trout, Salmo trutta caspius, and its effects on spermatozoa motility and fertilizing ability compared to freshwater and a saline medium. Fish Physiol Biochem 35: 695-700.

Jamieson BGM, Tudge CC. 2000. 1. Crustacea-Decapoda. In: Jamieson BGM, ed. Progress in Male Gamete Ultrastructure and Phylogeny, vol. 9, Part C of Adiyodi KG, Adiyodi RG, eds. Reproductive Biology of the Invertebrates. Chichester: John Wiley \& Sons, pp. 1-95.

Jeppesen E, Meerhoff M, Holmgren K, et al. 2010. Impacts of climate warming on lake fish community structure and potential effects on ecosystem function. Hydrobiologia 646: 73-90.

Jiravanichpaisal P, Söderhäll K, Söderhäll I. 2004. Effect of water temperature on the immune response and infectivity pattern of white spot syndrome virus (WSSV) in freshwater crayfish. Fish Shellfish Immunol 17: 265-275.

King HR, Pankhurst NW, Watts M, Pankhurst PM. 2003. Effect of elevated summer temperatures on gonadal steroid production, vitellogenesis and egg quality in female Atlantic salmon. $J$ Fish Biol 63: 153-167.

Köksal G. 1988. Astacus leptodactylus in Europe. In Holdich DM, Lowery RS, eds. Freshwater Crayfish: Biology, Management and Exploitation. London, UK: Croom Helm, pp. 365-400.

Kouba A, Niksirat H, Bláha M. 2015. Comparative ultrastructure of spermatozoa of the redclaw Cherax quadricarinatus and the yabby Cherax destructor (Decapoda, Parastacidae). Micron 69: 56-61.

Manning NJ, Kime DE. 1985. The effect of temperature on testicular steroid production in the rainbow trout, Salmo gairdneri, in vivo and in vitro. Gen Comp Endocrinol 57: 377-382.

Niksirat H, Kouba A. 2016. Subcellular localization of calcium deposits in the noble crayfish Astacus astacus spermatophore: implications for post-mating spermatophore hardening and spermatozoon maturation. J Morphol 277: 445-452.

Niksirat H, Kouba A, Rodina M, Kozak P. 2013a. Comparative ultrastructure of the spermatozoa of three crayfish species: Austropotamobius torrentium, Pacifastacus leniusculus, and Astacus astacus (Decapoda: Astacidae). J Morphol 274: 750-758.

Niksirat H, Kouba A, Pšenička M, Kuklina I, Kozák P. 2013b. Ultrastructure of spermatozoa from three genera of crayfish Orconectes, Procambarus and Astacus (Decapoda: Astacoidea): new findings and comparisons. Zool Anz 252: 226-233.

Niksirat H, Kouba A, Kozák P. 2014a. Post-mating morphological changes in the spermatozoon and spermatophore wall of the crayfish Astacus leptodactylus: insight into a non-motile spermatozoon. Anim Reprod Sci 149: 325-334.

Niksirat H, Andersson L, James P, Kouba A, Kozák P. 2014b. Proteomic profiling of the signal crayfish Pacifastacus leniusculus egg and spermatophore. Anim Reprod Sci 149: 335-344.

Niksirat H, James P, Andersson L, Kouba A, Kozák P. 2015. Labelfree protein quantification in freshly ejaculated versus post-mating spermatophores of the noble crayfish Astacus astacus. J Proteomics 123: 70-77.

Niksirat H, Vancová M, Andersson L, James P, Kouba A, Kozák P. 2016. Protein modification in the post-mating spermatophore of the signal crayfish Pacifastacus leniusculus: insight into the tyrosine phosphorylation in a non-motile spermatozoon. Anim Reprod Sci 172: 123-130.

Pankhurst NW, King HR. 2010. Temperature and salmonid reproduction: implications for aquaculture. J Fish Biol 76: 69-85.

Pascual C, Valera E, Re-Regis C, et al. 1998. Effect of water temperature on reproductive tract condition of Penaeus setiferus adult males. $J$ World Aquacult 29: 477-484.

Pascual C, Sánchez A, Sánchez A, Vargas-Albores F, LeMoullac G, Rosas C. 2003. Haemolymph metabolic variables and immune response in Litopenaeus setiferus adult males: the effect of an extreme temperature. Aquaculture 218: 637-650.

Paul C, Murray AA, Spears N, Saunders PT. 2008. A single, mild, transient scrotal heat stress causes DNA damage, subfertility and impairs formation of blastocysts in mice. Reproduction 136: 73-84.

Pérez-Crespo M, Pintado B, Gutiérrez-Adán A. 2008. Scrotal heat stress effects on sperm viability, sperm DNA integrity, and the offspring sex ratio in mice. Mol Reprod Dev 75: 40-47.

Perez-Velazquez M, Bray WA, Lawrence AL, Gatlin, III DM, Gonzalez-Felix ML. 2001. Effect of temperature on sperm quality of captive Litopenaeus vannamei broodstock. Aquaculture 198: 209-218.

Poff NL, Brinson MM, Day JW. 2002. Aquatic ecosystems and global climate change. Pew Center on Global Climate Change, Arlington, VA 44: 1-36.

Safaa HM, Emarah ME, Saleh NFA. 2008. Seasonal effects on semen quality in Black Baladi and white New Zealand rabbit bucks. World Rabbit Sci 16: 13-20. 
Sánchez A, Pascual C, Sánchez A, Vargas-Albores F, Le Moullac G, Rosas C. 2001. Hemolymph metabolic variables and immune response in Litopenaeus setiferus adult males: the effect of acclimation. Aquaculture 198: 13-28.

Skurdal J, Taugbøl T. 2002. Astacus, crayfish of commercial importance. In: Holdich, ed. Biology of Freshwater Crayfish. Oxford: Blackwell Publishing Ltd, pp. 467-503.

Thijssen A, Klerkx E, Huyser C, Bosmans E, Campo R, Ombelet W. 2014. Influence of temperature and sperm preparation on the quality of spermatozoa. Reprod Biomed Online 28: 436-442.

Tropea C, Piazza Y, Greco LSL. 2010. Effect of long-term exposure to high temperature on survival, growth and reproductive parameters of the "redclaw" crayfish Cherax quadricarinatus. Aquaculture 302: $49-56$.

Tudge CC. 2009. Spermatozoal morphology and its bearing on decapod phylogeny. In: Martin JW, Crandall A, Felder DL, eds.
Crustacean Issues: Decapod Crustacean Phylogenetics. Boca Raton: Francis \& Taylor/CRC Press, pp. 101-119.

Wickins JF, Lee DOC. 2002. Crustacean Farming Ranching and Culture. Oxford: Blackwell Science, 446 p.

Wittmann AC, Pörtner HO. 2013. Sensitivities of extant animal taxa to ocean acidification. Nat Clim Change 3: 995-1001.

Yazicioglu B, Hamr P, Kozák P, Kouba A, Niksirat H. 2016. Fine structure of the spermatozoon in three species of Cambaridae (Arthropoda: Crustacea: Decapoda) Cambarus robustus, Orconectes propinquus and Orconectes rusticus: a comparative biometrical study. PeerJ 4: 2363.

Yazicioglu B, Kouba A, Kozák P, Niksirat H. 2018. Post-mating spermatophore storage strategies in two species of crayfish: implications for broodstock management. Animal 12: 554-558.

Yeh HS, Rouse DB. 1995. Effects of water temperature, density, and sex ratio on the spawning rate of red claw crayfish Cherax quadricarinatus (von Martens). $J$ World Aquacult 26: 160-164.

Cite this article as: Farhadi A, Harlıglu MM. 2018. Elevated water temperature impairs gamete production in male narrow-clawed crayfish Pontastacus leptodactylus (Eschscholtz, 1823). Knowl. Manag. Aquat. Ecosyst., 419, 40. 